\title{
Enzyme Studies of Sucrose Decline in Sugarcane Desiccated with Paraquat ${ }^{1}$
}

\author{
Alex G. Alexander and Rafael Montalvo-Zapata ${ }^{2}$
}

\section{INTRODUCTION}

Although preharvest burning is a necessary step for mechanical harvesting of sugarcane, a serious problem has been incomplete burning due to high moisture content of the green tops (1). ${ }^{3}$ Thus the use of chemicals as desiccating agents, a theoretically sound practice (34), has gained genuine interest throughout the sugarcane world.

The quaternary ammonium compounds Paraquat and Diquat ${ }^{4}$ have been widely tested but with inconsistent results. Studies with Diquat in Jamaica (27) have given good desiccation of leaves while sucrose subsequently declined. Gosnell and Thompson (29) reported a reduction of cane yield in response to Paraquat. Bates (21) studied the effects of 12 desiccants on mature cane and concluded that Diquat and Paraquat possessed the most desirable properties.

Little attention has been given to the mechanisms by which desiccants cause sucrose content to decline. Thus an investigator has no clear basis for seeking new desiccants, for evaluating their action, or for knowing whether better use might have been made of previous ones. With this in mind a series of physiological and biochemical studies has been initiated with desiccants in Puerto Rico.

This paper deals with two experiments in which enzymes of immature sugarcane were measured concurrently with Paraquat-induced desiccation and sugar transformations. There were two objectives: 1, To determine whether sugar changes could be correlated with abnormal behavior of hydrolytic or oxidative enzymes; and 2, to study the persistence of desiccantinduced sugar and enzyme changes under conditions of powerful growth stimuli.

\section{MATERIALS AND METHODS}

\section{GROWTH AND SAMPLING OF PLANT MATERIALS}

Two greenhouse experiments were conducted with Paraquat. In the first, sugar and enzyme changes were measured periodically following a single

$11,1^{\prime}$-dimethyl-4,4'-bipyridilium-bis-dimethyl sulfate. This compound is known commercially as (iramoxone.

2 Plant Physiologist and Assistant Chemist, Agricultural Experiment Station, Mayagüez Campus, University of Puerto Rico, Río Piedras, P.IR.

3 Italic numbers in parentheses refer to Literature Cited, pp. 249-250.

$+1,1^{\prime}$-et hylene-2,2'-dipyridilium dibromide. 
foliar application. The second experiment employed variable nitrate $\left(\mathrm{NO}_{3}\right)^{5}$ and gibberellic acid (GA) to induce extreme growth regimes prior to Paraquat treatment. All plants were grown in sand culture as previously described (2).

For experiment 1 a single $0 . \bar{j}$-percent aqueous Paraquat solution was applied to 16-week-old plants of the variety P.R. 980. Tween 20 was used as wetting agent at the rate of $1.0 \mathrm{ml}$./liter. The solution was applied with a Hudson hand-sprayer until runoff had begun. Control plants received distilled water plus Tween 20. Each of the two treatments was replicated three times in a completely randomized greenhouse design. Leaf and immature storage tissues were sampled a few moments prior to treatment and subsequent harvests were made at 24,48 , and 72 , and 168 hours. The tissues were frozen in a mixture of dry ice and acetone, lyophilized, ground to pass a 60 -mesh screen, and stored at $0^{\circ} \mathrm{C}$. in accordance with procedures described previously (2). Leaf sheaths were retained for percent-moisture determinations and millable stalks were ground with a small laboratory mill for Brix and polarization analyses.

Experiment 2 was initiated at 14 weeks with the varieties P.R. 980 and P.R. 1059. The plants were divided into two equal groups, the first of which was given variable $\mathrm{NO}_{3}$ and the other variable GA. Nitrate levels of 1 and $50 \mathrm{meq}$./liter were provided in daily nutrient solutions for the duration of the study. The second group was treated with foliar GA in aqueous solutions equivalent to 0 and 0.01 percent of the pure acid. A single application was made at 14 weeks with Tween 20 serving as wetting agent. At 16 weeks, with differential $\mathrm{NO}_{3}$ and GA regimes considered to be well established, Paraquat was applied at levels of 0 and 0.5 percent. A single application was made in the manner described for experiment 1 . The $\mathrm{NO}_{3}$ and GA groups were maintained in separate randomized blocks with three replicates of each treatment. A single harvest was made 7 days after the desiccant treatments.

\section{LABORATORY ANALYSES}

Clarified water extracts of the plant powder were analyzed for total ketose by the resorcinol method of Roe (35) and for sucrose by the modification of Cardini $c t$ al. (25). Fructose was estimated by subtracting sucrose values from those of total ketose. Total reducing sugars were estimated by the dinitrosalicylic acid method of Sumner (36).

Protein was precipitated from water extracts with solid ammonium sulfate as described previously (2). The 0-80-percent fraction was retained for enzyme assay without dialysis. Acid phosphatase and ATP-ase were measured in accordance with methods described earlier (5), as were invertase

s Abbreviations: Nitrate $\left(\mathrm{NO}_{3}\right)$; gibberellic acid (GA); Beta-glycerophosphate $(\beta-G P)$; adenosine triphosphate (ATP). 
(6), amylase (7), polyphenol oxidase (9), and peroxidase (8). The technique of Sutherland et al. (37) was used to measure both the water-soluble protein of tissue samples and the protein content of enzyme preparations. Enzyme action is expressed as specific activity (activity units per milligram of protein).

Samples of leaf extracts were chromatographed on Whatman No. 1 filter paper, using the solvent mixture butanol-pyridine-water $(6: 4: 3, \mathrm{v} / \mathrm{v})$ in one dimension. The water extracts were concentrated by lyophilization prior to application. Authentic and unknown sugar spots were developed by the silver nitrate method of Dube and Nordin (28).

Biochemicals employed during these investigations were supplied by Nutritional Biochemicals Corp., Cleveland, Ohio. Ribulose-5-phosphate was purchased from the Sigma Chemical Co., St. Louis, Mo., and Gram-

TaBLe 1.-Growth responses of immalure sugarcane trealed with Paraqual

\begin{tabular}{|c|c|c|c|c|c|c|c|}
\hline \multirow{2}{*}{ Data class } & \multirow{2}{*}{$\begin{array}{l}\text { Treatment } \\
\text { (Paraquat) }\end{array}$} & \multicolumn{5}{|c|}{ Hours following treatment- } & \multirow{2}{*}{ Mean } \\
\hline & & $\mathbf{0}$ & 24 & 48 & 72 & 168 & \\
\hline \multirow{3}{*}{ Total fresh wt. (g.) } & Percent & & & & & & \\
\hline & 0 & 161 & 160 & 167 & 217 & 208 & 183 \\
\hline & .5 & 208 & 227 & 189 & 132 & 95 & 170 \\
\hline \multirow[t]{2}{*}{ Stalk wt. (g.) } & 0 & 57 & 60 & 60 & 60 & 70 & 63 \\
\hline & .5 & 72 & 76 & 82 & 57 & 38 & 69 \\
\hline \multirow[t]{2}{*}{ Sheath moisture $(\%)$} & $\mathbf{0}$ & 78.9 & 81.2 & 80.0 & 84.3 & 80.1 & 80.9 \\
\hline & .5 & 78.7 & 80.9 & 79.6 & 71.7 & 54.8 & 73.1 \\
\hline
\end{tabular}

1 Each figure represents the computed mean of 3 replicates.

oxone (Paraquat) was supplied by a local representative of the Chevron Chemical Co., Ortho Division.

\section{RESULTS AND DISCUSSION}

All Paraquat-treated plants revealed severe desiccation within 72 hours. The drying of plant tissues was accompanied by measurable enzyme and sugar transformations. The latter were verified under conditions of $\mathrm{NO}_{3}$ and GA stress.

EXPERIMENT 1: PARAQUAT vs. TIME

\section{Growth Responses to Paraquat}

A general wilting of desiccant-treated foliage was evident within $S$ hours. By 36 hours the leaf and spindle tissues were severely desiccated and exhibited a greyish-yellow color. Sheath percent moisture declined sharply by 72 hours, but moisture loss for millable stalks was not severe prior to the 168-hour harvest (table 1). 


\section{Sugar Responses}

A major loss of leaf sucrose accompanied the desiccation and was readily detected within 24 hours (fig. 1). Moderate increases in reducing sugar content suggest that part of the loss was accountable to inversion (table 2). However, this should also reflect an increasing impairment of photosynthesis.

Sucrose of immature storage tissue did not exhibit a similar abrupt decline (table 2). Brix and polarization values were at first increased slightly, but were notably suppressed by 72 hours, and remained low at 168 hours

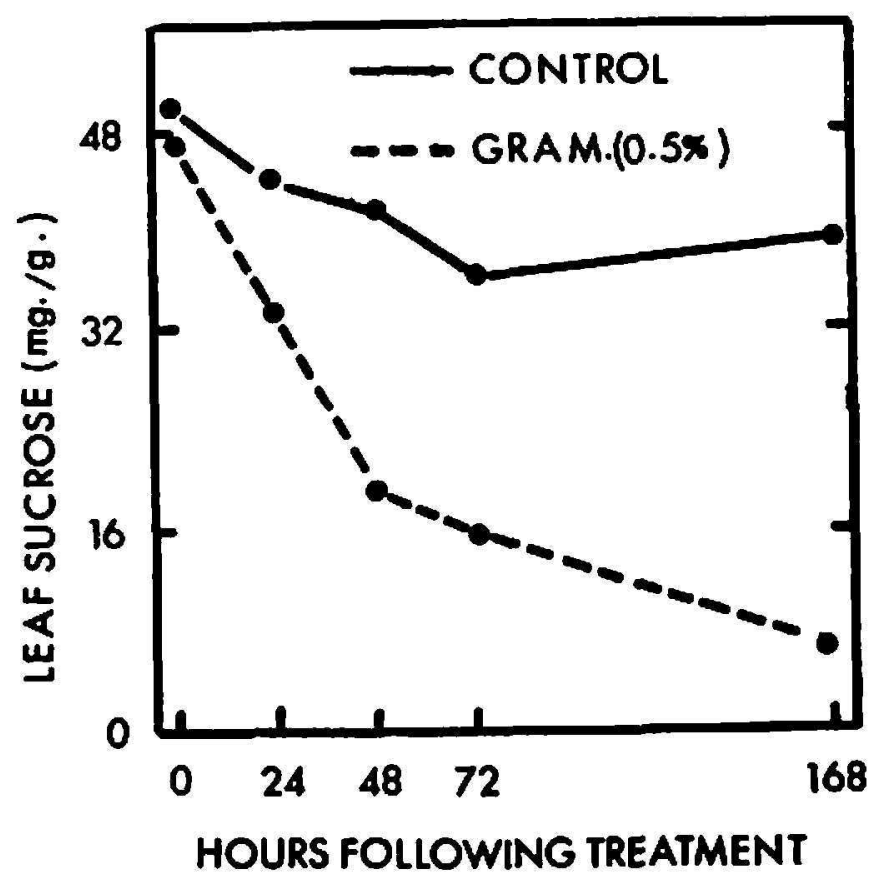

Frg. 1.-Leaf sucrose decline in leaves of immature sugarcane treated with foliar Paraquat (Gramoxone).

(fig. 2). This supports the findings of Davidson (27) who reported Brix decline 4 days after Diquat application.

A significant clue to the mode of Paraquat action was revealed by paper chromatography of leaf extracts. The chromatograms were originally intended to verify sucrose losses and higher levels of reducing sugars. But, in addition, there was discovered ribose plus increased raffinose and several unidentified sugars in leaves treated with desiccant (fig. 3). Ribose appeared during the 24- to 48-hour period, after severe wilting had occurred, which roughly corresponds to the initial chlorophyll losses. Both photosynthesis and post-photosynthetic sugar transformations are thus implicated in Paraquat action.

Following the early discoveries of hexose phosphates among photosynthetic products of Chlorella pyrenoidosa (23,24), the 5-carbon compounds 
TABLe 2.-Sugar responses of immalure sugarcane trealed with Paraquat

\begin{tabular}{|c|c|c|c|c|c|c|c|c|}
\hline \multirow{2}{*}{ Tissue } & \multirow{2}{*}{$\begin{array}{c}\text { Data } \\
\text { class }^{2}\end{array}$} & \multirow{2}{*}{$\begin{array}{l}\text { Paraquat } \\
(\% \text { soln. })\end{array}$} & \multicolumn{5}{|c|}{ Hours following treatment- } & \multirow{2}{*}{ Mean } \\
\hline & & & 0 & 24 & 48 & 72 & 168 & \\
\hline \multirow[t]{4}{*}{ Leaf } & \multirow[t]{2}{*}{ Sucrose } & 0 & 49.4 & 44.1 & 41.7 & 36.2 & 39.3 & 42.1 \\
\hline & & .5 & 46.9 & 33.3 & 19.6 & 16.0 & 7.2 & 24.6 \\
\hline & \multirow{2}{*}{$\begin{array}{l}\text { Reducing } \\
\text { sugars }\end{array}$} & 0 & 21.0 & 22.7 & 23.4 & 25.5 & 19.9 & 22.5 \\
\hline & & .5 & 22.9 & 28.3 & 33.2 & 38.3 & 26.4 & 29.8 \\
\hline \multirow{4}{*}{$\begin{array}{c}\text { Immature } \\
\text { storage }\end{array}$} & \multirow[t]{2}{*}{ Sucrose } & 0 & 61.8 & 40.5 & 30.7 & 24.8 & 53.8 & 42.3 \\
\hline & & .5 & 45.7 & 52.5 & 55.5 & 46.2 & 49.9 & 50.0 \\
\hline & \multirow{2}{*}{$\begin{array}{l}\text { Reducing } \\
\text { sugars }\end{array}$} & 0 & 173 & 167 & 195 & 201 & 191 & 185 \\
\hline & & .5 & 197 & 169 & 168 & 196 & 167 & 179 \\
\hline \multirow[t]{4}{*}{ Stalk } & \multirow[t]{2}{*}{ Brix } & 0 & 4.6 & 4.2 & 6.3 & 7.6 & 5.9 & 5.7 \\
\hline & & .5 & 5.5 & 5.2 & 7.5 & 4.7 & 2.1 & 5.0 \\
\hline & \multirow[t]{2}{*}{ Pol. } & $\mathbf{0}$ & 8.1 & 9.9 & 15.5 & 18.2 & 13.0 & 12.9 \\
\hline & & .5 & 9.1 & 11.9 & 12.8 & 9.1 & 7.8 & 10.1 \\
\hline
\end{tabular}

1 Each figure represents the computed mean of 3 replicates.

2 Total ketose, sucrose, and reducing-sugar values are expressed as milligrams per gram of dry weight.

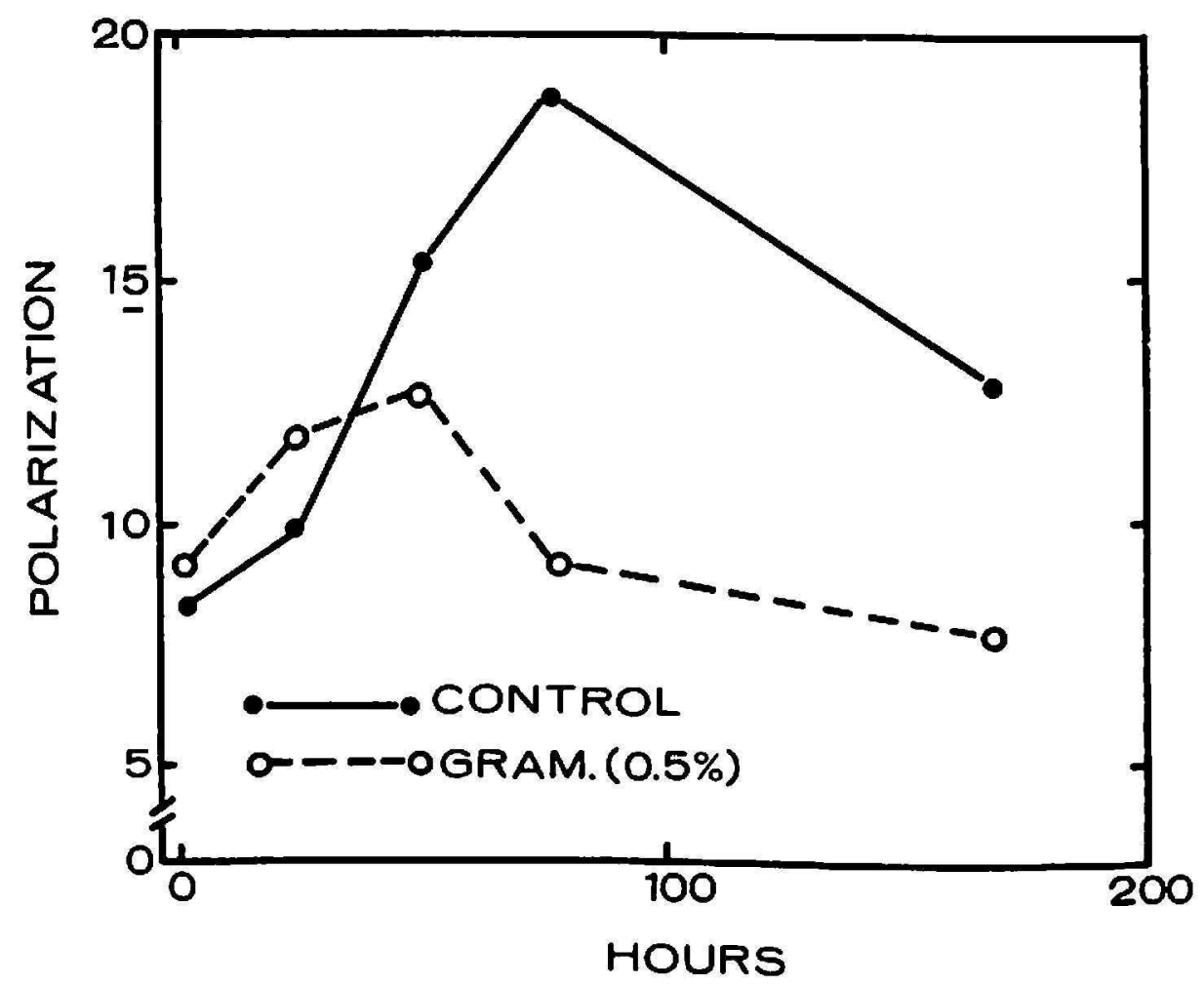

Frg. 2.-Decline of polarization values for sugarcane treated with foliar Paraquat (Gramoxone).

ribose-5-phosphate and ribulose-5-phosphate were reported by Benson et al. (22). Ribose-5-phosphate is believed to arise as one product of a transketolase-catalyzed reaction between thiamine pyrophosphate and sedoheptulose-7-phosphate (20,p.888): 


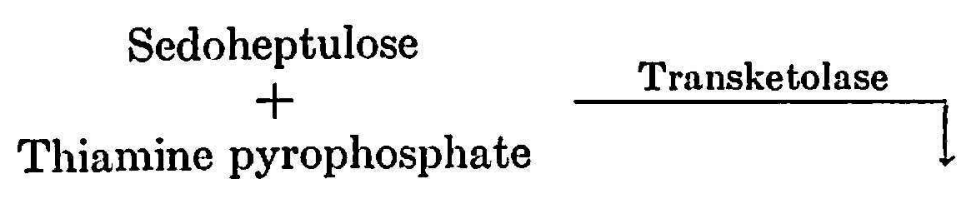

Thiamine pyrophosphate-glycoaldehyde $+$

R:bose-5-phosphate

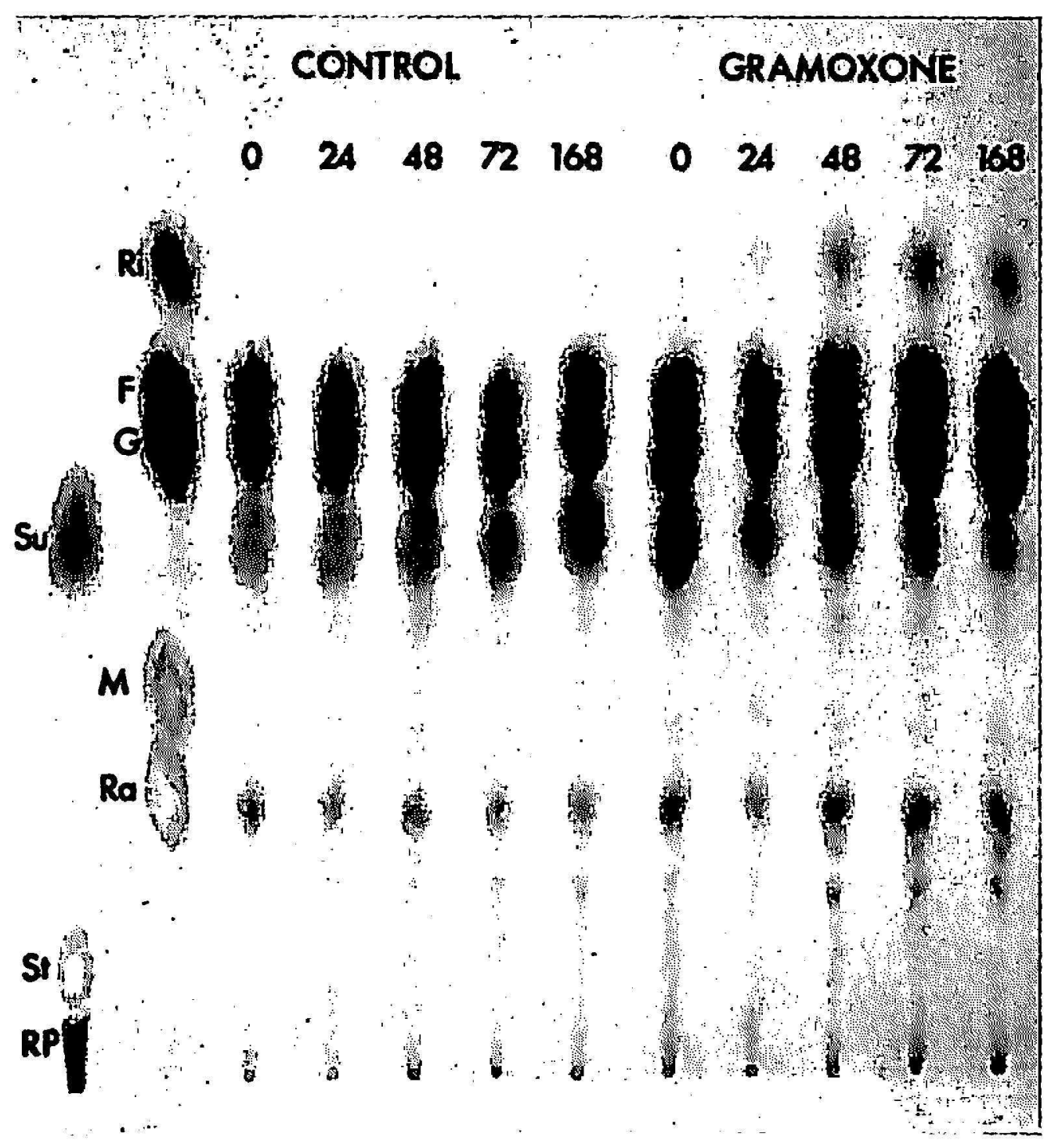

Fig. 3.-Paper chromatography of leaf extracts from immature sugarcane treated with foliar Paraquat (Gramoxone). Letters appearing adjacent to reference sugars signify the following (from top to bottom): Ri, ribose; F, fructose; G, glucose; Su, sucrose; M, melezitose; Ra, raffinose; St, stachyose; RP, ribose-5-phosphate. Numbers refer to harvest periods in hours from time of desiccant application.

The enzyme phosphoribose isomerase converts ribose-5-phosphate to ribulose-5-phosphate (19), involving a shift of the keto position from carbon 1 to carbon 2: 


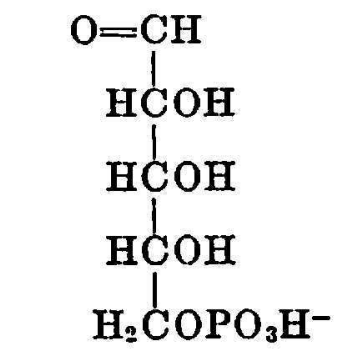

Ribose-5-Phosphate

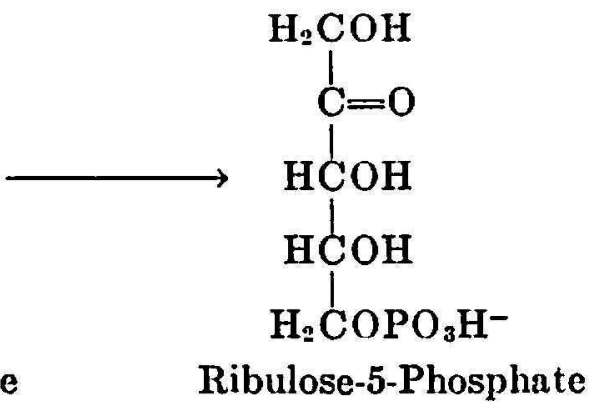

Ribulose-5-Phosphate

Assuming that a similar mechanism is active in cane for converting triose phosphate to pentose phosphate, ${ }^{6}$ it is suggested that Paraquat imposed a major photosynthetic block at the site of phosphoribose isomerase action. Subsequent accumulations of ribose-5-phosphate would then be hydrolyzed by ribose-5-phosphatase to yield free ribose in detectable quantities.

The increase of raffinose and unknown sugars of lesser mobility may reflect transferase action involving sucrose as an acceptor of hexose residues. The possibility that invertases can take part in such reactions has been suggested earlier (12). In vitro studies have shown that silicon may increase the capacity of invertases to participate in this type of reaction (14). However, foliar Paraquat is the only in vivo treatment tested here which has caused these rarer sugars to increase.

\section{Enzyme Responses}

The most significant enzyme change recorded was that of leaf amylase in response to Paraquat (table 3). By 24 hours the enzyme was three times more active in Paraquat plants than controls (fig. 4). At 72 hours, when plants were severely wilted and photosynthesis impaired, amylase was still about 2 times more active. At 168 hours amylase and all other enzymes measured had markedly declined in conjunction with death of the leaves.

The abnormal amylase behavior supports our contention that suppression of amylase is an essential prerequisite for maximum sucrose production (15). Physiological experiments have consistently correlated high sucrose with amylase decline $(2,4,10,18)$. The present experiment adds support to the low amylase-high sucrose theory by yielding consistently poor sugar values in plants having abnormally active amylase. Presumably high amylase activity permits excessive drainage of glucose-1-phosphate into polysaccharide-forming pathways. The sucrose status for desiccated plants must have been further worsened by the continuing amylase action as late

- A net flow of carbon from triose to pentose is needed under steady-state conditions for completion of the photosynthesis process. Since about a third of the ribulose phosphate is derived by phosphoribose activity $(20$, p. 889$)$, the action of Paraquat here alone has serious implications for plants employing the Chlorella pathways. 
TABLE 3.-Mean specific activity values for leaf enzymes of sugarcane treated with Paraqual 1

\begin{tabular}{|c|c|c|c|c|c|c|c|}
\hline \multirow{2}{*}{ Enzyme } & \multirow{2}{*}{$\begin{array}{l}\text { Paraquat } \\
\text { (\% soln.) }\end{array}$} & \multicolumn{5}{|c|}{ Hours after treatment- } & \multirow{2}{*}{ Mean } \\
\hline & & 0 & 24 & 48 & 72 & 168 & \\
\hline \multirow[t]{2}{*}{ Phosphatase } & $\mathrm{O}_{5}$ & 44.5 & 58.0 & 46.3 & 43.4 & 46.7 & 47.8 \\
\hline & .5 & 56.0 & 45.7 & 36.8 & 25.7 & 14.3 & 35.7 \\
\hline \multirow[t]{2}{*}{ ATP-ase } & 0 & 104.9 & 97.4 & 46.3 & 43.4 & 46.6 & 67.7 \\
\hline & .5 & 130.4 & 69.0 & 36.8 & 25.7 & 14.3 & 55.2 \\
\hline \multirow[t]{2}{*}{ Amylase } & 0 & 26.7 & 30.8 & 55.3 & 53.1 & 34.4 & 40.1 \\
\hline & .5 & 28.7 & 90.9 & 116.3 & 125.9 & 23.8 & 77.1 \\
\hline \multirow[t]{2}{*}{ Tyrosinase } & 0 & 17.0 & 20.5 & 14.5 & 15.0 & 12.3 & 15.9 \\
\hline & .5 & 22.5 & 30.5 & 29.0 & 33.3 & 6.7 & 24.4 \\
\hline \multirow[t]{2}{*}{ Peroxidase } & 0 & 129.3 & 137.1 & 131.4 & 126.7 & 123.7 & 129.6 \\
\hline & .5 & 141.7 & 117.1 & 112.8 & 103.7 & 17.1 & 98.5 \\
\hline
\end{tabular}

1 Each figure represents the computed mean of 3 replicates.

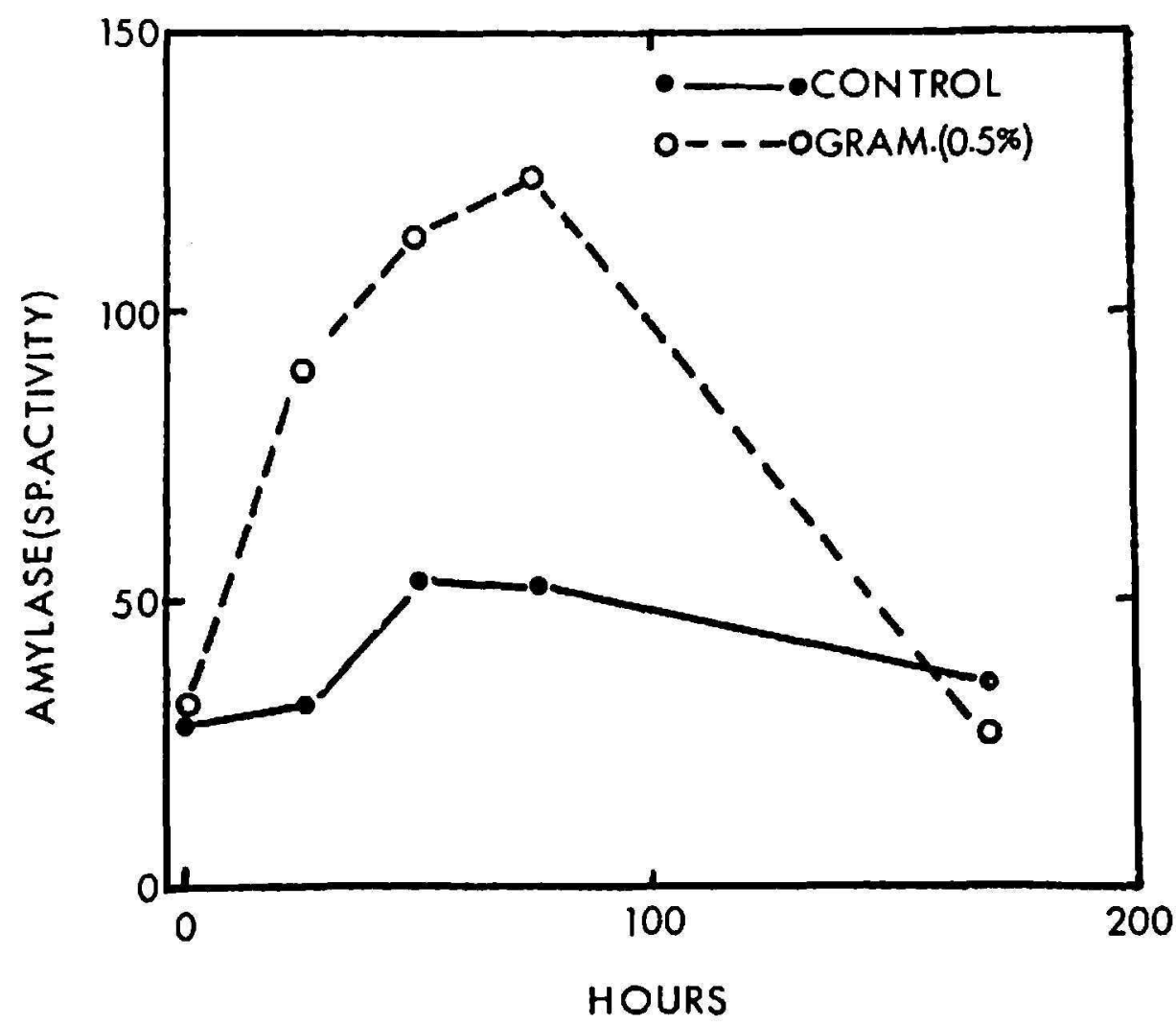

Fra. 4.-Excessive amylase action in cane leaves after treatment with foliar Paraquat (Gramoxone).

as 72 hours, well after the replacement of sugars via photosynthesis must have ceased.

Invertase was suppressed within 24 hours and thereafter remained well below control values (table 4). Other factors being constant, one might have 
expected sucrose increases as a consequence of invertase decline. Possibly the initial increases for Brix values and sucrose content of immature storage tissues do reflect the early invertase suppression. However, in order for any prolonged and meaningful ripening effect to accompany foliar desiccation, it appears that photosynthetic mechanisms must remain operative and both amylase and invertase action must be held below normal.

\section{experiment 2: Paraquat vs. $\mathrm{NO}_{3}$ and GA}

\section{Growth Responses to Paraquat}

Data taken seven days after Paraquat treatment generally verified the growth effects noted in experiment 1 . Although figures are not available for

TABLE 4.-Mean specific activity values for enzymes from immalure slorage lissue of sugarcane treated with Paraquat

\begin{tabular}{|c|c|c|c|c|c|c|c|}
\hline \multirow{2}{*}{ Enzyme } & \multirow{2}{*}{$\begin{array}{l}\text { Paraquat } \\
\text { (\% soln.) }\end{array}$} & \multicolumn{5}{|c|}{ Hours after treatment- } & \multirow{2}{*}{ Mean } \\
\hline & & 0 & 24 & 48 & 72 & 168 & \\
\hline \multirow{2}{*}{ Phosphatase } & 0 & 93.8 & 75.9 & 73.2 & 73.6 & 73.8 & 78.1 \\
\hline & .5 & 106.1 & 68.2 & 80.1 & 71.7 & 47.6 & 74.7 \\
\hline \multirow[t]{2}{*}{ ATP-ase } & 0 & 194.0 & 195.6 & 114.6 & 120.7 & 92.8 & 143.5 \\
\hline & .5 & 184.5 & 124.9 & 133.1 & 104.2 & $\mathbf{5 7 . 8}$ & 120.9 \\
\hline \multirow[t]{2}{*}{ Amylase } & 0 & 44.2 & 35.6 & 25.7 & 56.2 & 50.8 & 42.5 \\
\hline & .5 & 36.0 & 46.8 & 76.7 & 52.6 & 42.9 & 51.0 \\
\hline \multirow{2}{*}{ Invertase } & $\mathbf{0}$ & 14.2 & 15.2 & 23.5 & 27.5 & 18.6 & 19.9 \\
\hline & .5 & 17.4 & 11.7 & 9.4 & 13.3 & 4.3 & 11.2 \\
\hline \multirow[t]{2}{*}{ Tyrosinase } & 0 & 11.7 & 7.8 & 6.7 & 6.5 & 8.0 & 8.1 \\
\hline & .5 & 10.5 & 6.7 & 7.3 & 6.6 & 6.8 & 7.6 \\
\hline \multirow[t]{2}{*}{ Peroxidase } & 0 & 37.5 & 27.8 & 24.3 & 22.3 & 25.7 & 27.5 \\
\hline & .5 & 30.5 & 25.6 & 27.3 & 23.6 & 20.0 & 25.4 \\
\hline
\end{tabular}

1 Each figure represents the computed mean of 3 replicates.

low $\mathrm{NO}_{3}$, it is clear that high $\mathrm{NO}_{3}$ supply was unable to block desiccant action (table 5). Paraquat suppression of fresh weight and sheath moisture was more pronounced in P.R. 980, a high tonnage variety, than in the high sucrose variety P.R. 1059.

Plants treated with GA were also unable to withstand the desiccating action of Paraquat (table 6). Gibberellic acid gave notably greater weight increases for millable stalks, particularly in P.R. 1059, indicating that GAtreated plants were experiencing stimulated growth at the time of Paraquat application. Sheath-moisture and fresh-weight data indicate that Paraquat caused greater desiccation in GA-treated plants of both varieties. The GAinduced internode elongation did not permit greater stalk desiccation, and the drying effects were again confined to leaves and sheaths. 


\section{Sugar Responses}

Sugar responses to Paraquat in experiment 2 verified those of experiment 1. Leaf sucrose content was severely suppressed by Paraquat regardless of $\mathrm{NO}_{3}$ supply and variety (table 7). Sugars of immature storage tissues did not reflect the foliar desiccant action.

Gibberellic acid also failed to alter the Paraquat effects on leaf sugars (table 8). Paraquat consistently reduced leaf sucrose content, regardless of GA treatment or variety. In each instance the desiccant suppression of sucrose was accompanied by marked increases of reducing sugars. The Para-

TABLE 5.-Growth of sugarcane in response to foliar Paraqual under condition of nitrate stress 1

\begin{tabular}{|c|c|c|c|c|c|c|}
\hline \multirow[b]{2}{*}{ Var. } & \multicolumn{2}{|c|}{ Treatment- } & \multicolumn{4}{|c|}{ Data classification- } \\
\hline & $\underset{\text { (meq./l.) }}{\mathrm{NO}}$ & $\begin{array}{l}\text { Paraquat } \\
\text { (\% soln.) }\end{array}$ & $\begin{array}{c}\text { Total fregb } \\
\text { wt. (g.f } \\
\text { plant) }\end{array}$ & $\begin{array}{l}\text { Millable } \\
\text { stalk wt. } \\
\text { (g./stalk) }\end{array}$ & $\begin{array}{l}\text { Internode } \\
\text { length } \\
\text { (in.) }\end{array}$ & $\begin{array}{c}\text { Sheatb } \\
\% \\
\text { moisture }\end{array}$ \\
\hline P.R. 980 & $\begin{array}{l}1.0 \\
50\end{array}$ & $\begin{array}{l}0^{0} \\
0^{.5}\end{array}$ & $\begin{array}{r}162 \\
-2 \\
163 \\
95\end{array}$ & $\begin{array}{l}43 \\
33 \\
40\end{array}$ & $\begin{array}{l}2.6 \\
- \\
2.8 \\
2.8\end{array}$ & $\begin{array}{c}80.9 \\
- \\
81.3 \\
28.4\end{array}$ \\
\hline & \multicolumn{2}{|c|}{ Variety mean } & 140 & 39 & 2.7 & 63.5 \\
\hline \multirow[t]{2}{*}{ P.R. 1059} & $\begin{array}{l}1.0 \\
50\end{array}$ & $\begin{array}{l}0 \\
{ }^{0} .5 \\
.5\end{array}$ & $\begin{array}{r}116 \\
111 \\
85\end{array}$ & $\begin{array}{l}\frac{61}{-} \\
57 \\
47\end{array}$ & $\begin{array}{l}2.1 \\
- \\
2.2 \\
2.2\end{array}$ & $\begin{array}{c}82.7 \\
- \\
82.6 \\
62.0\end{array}$ \\
\hline & \multicolumn{2}{|c|}{ Variety mean } & 104 & 55 & 2.2 & 76.1 \\
\hline
\end{tabular}

1 Each figure represents the computed mean of 3 replicates.

2 Data not available.

quat effects were again largely confined to leaves. As was true in experiment 1 , in the absence of GA, Paraquat caused slight sucrose increases for immature storage tissue.

Paper chromatography again revealed ribose, raffinose and several unidentified sugars in leaves treated with Paraquat (fig. 5). Careful study of figure 5 confirms the loss of sucrose and general increase of reducing sugars in response to Paraquat. Varietal effects are also obvious for sucrose. However, most significant is the persistent appearance of ribose and trisaccharide in spite of the superimposed varietal and physiological factors. Variety must certainly be regarded as a major factor in determining sugar production throughout the sugarcane world. Studies in Puerto Rico have 
TABLE 6.-Growth of two sugarcane varielies in response to foliar Paraquat under conditions of gibberellic acid stress ${ }^{1}$

\begin{tabular}{|c|c|c|c|c|c|c|}
\hline \multirow[b]{2}{*}{ Var. } & \multicolumn{2}{|c|}{ Treatment- } & \multicolumn{4}{|c|}{ Data classification- } \\
\hline & (\% soln.) & $\begin{array}{l}\text { Paraquat } \\
\text { (\% soln.) }\end{array}$ & $\begin{array}{c}\text { Total fresh } \\
\text { wt. (s. } \\
\text { /plant) }\end{array}$ & $\begin{array}{l}\text { Millable } \\
\text { stalk wt. } \\
\text { (g./stalk) }\end{array}$ & $\begin{array}{l}\text { Internode } \\
\text { length } \\
\text { (in.) }\end{array}$ & $\begin{array}{c}\text { Sheath } \\
\% \\
\% \\
\text { moisture }\end{array}$ \\
\hline \multirow[t]{3}{*}{ P.R. 980} & $\mathbf{0}$ & $\begin{array}{l}0 \\
.5\end{array}$ & $\begin{array}{r}130 \\
78\end{array}$ & $\begin{array}{l}45 \\
42\end{array}$ & $\begin{array}{l}2.5 \\
2.7\end{array}$ & $\begin{array}{l}81.3 \\
51.9\end{array}$ \\
\hline & \multicolumn{2}{|c|}{ GA mean } & 104 & 43.5 & 2.6 & 66.6 \\
\hline & .01 & $\begin{array}{l}0 \\
.5\end{array}$ & $\begin{array}{l}140 \\
121\end{array}$ & $\begin{array}{l}59 \\
69\end{array}$ & $\begin{array}{l}4.6 \\
4.4\end{array}$ & $\begin{array}{l}79.3 \\
31.7\end{array}$ \\
\hline \multicolumn{3}{|c|}{ GA mean } & 130 & 64 & 4.5 & 55.5 \\
\hline \multirow[t]{3}{*}{ P.R. 1059} & 0 & $\begin{array}{l}0 \\
.5\end{array}$ & $\begin{array}{r}114 \\
92\end{array}$ & $\begin{array}{l}40 \\
46\end{array}$ & $\begin{array}{l}2.0 \\
2.0\end{array}$ & $\begin{array}{l}83.0 \\
52.2\end{array}$ \\
\hline & \multicolumn{2}{|c|}{ GA mean } & 103 & 43 & 2.0 & 67.6 \\
\hline & .01 & $\begin{array}{l}0 \\
.5\end{array}$ & $\begin{array}{l}155 \\
106\end{array}$ & $\begin{array}{l}85 \\
83\end{array}$ & $\begin{array}{l}4.3 \\
4.0\end{array}$ & $\begin{array}{l}82.4 \\
23.0\end{array}$ \\
\hline \multicolumn{3}{|c|}{ GA mean } & 130 & 84 & 4.2 & 52.7 \\
\hline
\end{tabular}

1 Each figure represents the computed mean of 3 replicates.

TABLE 7.-Sugar content of \& sugarcane varieties treated with Paraqual and grown under conditions of nitrate stress ${ }^{2}$

\begin{tabular}{|c|c|c|c|c|c|c|}
\hline \multirow{3}{*}{ Var. } & \multirow{3}{*}{$\underset{\text { (meq./l.) }}{\mathrm{NO}_{3}}$} & \multirow{3}{*}{$\begin{array}{l}\text { Paraquat } \\
\text { (\% soln.) }\end{array}$} & \multicolumn{4}{|c|}{ Sugar content (mg./g.) for- } \\
\hline & & & \multicolumn{2}{|c|}{ Leaf } & \multicolumn{2}{|c|}{ Immature storage tissue } \\
\hline & & & Sucrose & Reducing & Sucrose & Reducing \\
\hline \multirow[t]{4}{*}{ P.R. 980} & 1 & 0 & 43.1 & 12.8 & 47.8 & 118 \\
\hline & & .5 & -2 & - & - & - \\
\hline & 50 & 0 & 35.0 & 16.2 & 33.3 & 182 \\
\hline & & .5 & 8.3 & 33.7 & 33.9 & 83 \\
\hline \multirow[t]{4}{*}{ P.R. 1059} & 1 & 0 & 71.9 & 19.7 & 44.2 & 102 \\
\hline & & .5 & -2 & - & - & - \\
\hline & 50 & 0 & 42.2 & 21.2 & 28.4 & 136 \\
\hline & & .5 & 10.4 & 53.9 & 42.7 & 94 \\
\hline
\end{tabular}

1 Each figure represents the computed mean of 3 replicates.

Data not available. 
shown that variable levels of $\mathrm{NO}_{3}(2,10)$ and GA $(11,16)$ are extremely powerful regulators of sugar production. Yet none of these could markedly divert Paraquat from expressing its own sugar-regulating potential.

\section{Enzyme Responses}

Leaf enzymes were generally suppressed by Paraquat. The single harvest for experiment 2 gave results similar to the comparable, 168-hour harvest

TABLE 8.-Sugar conlent of 2 sugarcane varielies trealed with Paraqual and grown under conditions of gibberellic acid stress ${ }^{1}$

\begin{tabular}{|c|c|c|c|c|c|c|c|c|}
\hline \multirow{3}{*}{ Var. } & \multicolumn{2}{|c|}{ Treatment- } & \multicolumn{6}{|c|}{ Sugar content (mg./g.) for- } \\
\hline & \multirow{2}{*}{$\begin{array}{c}\mathrm{GA} \\
\text { (\% soln.) }\end{array}$} & \multirow{2}{*}{$\begin{array}{l}\text { Paraquat } \\
(\% \text { soln.) }\end{array}$} & \multicolumn{2}{|c|}{ Leaf } & \multicolumn{2}{|c|}{ Immature storage } & \multicolumn{2}{|c|}{ Stalk } \\
\hline & & & Sucrose & Reducing & Sucrose & Reducing & Brix & Pol. \\
\hline P.R. 980 & 0 & $\begin{array}{l}0 \\
.5\end{array}$ & $\begin{array}{l}36.5 \\
10.1\end{array}$ & $\begin{array}{l}16.7 \\
40.0\end{array}$ & $\begin{array}{l}39.0 \\
56.3\end{array}$ & $\begin{array}{l}113 \\
90.0\end{array}$ & $\begin{array}{l}7.5 \\
3.4\end{array}$ & $\begin{array}{r}16.2 \\
4.2\end{array}$ \\
\hline & \multicolumn{2}{|c|}{ GA mean } & 23.3 & 28.2 & 47.7 & 101 & 5.5 & 10.2 \\
\hline & .01 & $\begin{array}{l}0 \\
.5\end{array}$ & $\begin{array}{l}49.6 \\
11.7\end{array}$ & $\begin{array}{l}20.0 \\
48.8\end{array}$ & $\begin{array}{l}46.4 \\
46.5\end{array}$ & $\begin{array}{l}121 \\
91.0\end{array}$ & $\begin{array}{l}8.1 \\
5.2\end{array}$ & $\begin{array}{r}15.4 \\
5.3\end{array}$ \\
\hline & \multicolumn{2}{|c|}{ GA mean } & 30.7 & 34.4 & 46.5 & 106 & 6.7 & 10.5 \\
\hline \multirow[t]{3}{*}{ P.R. 1059} & $\mathbf{0}$ & $\begin{array}{l}0 \\
.5\end{array}$ & $\begin{array}{l}48.0 \\
18.8\end{array}$ & $\begin{array}{l}15.0 \\
47.2\end{array}$ & $\begin{array}{l}31.1 \\
38.4\end{array}$ & $\begin{array}{l}100 \\
109\end{array}$ & $\begin{array}{l}8.0 \\
5.3\end{array}$ & $\begin{array}{l}17.8 \\
10.7\end{array}$ \\
\hline & \multicolumn{2}{|c|}{ GA mean } & 33.4 & 21.1 & 34.8 & 105 & 6.7 & 14.3 \\
\hline & .01 & $\begin{array}{l}0 \\
.5\end{array}$ & $\begin{array}{l}51.2 \\
16.5\end{array}$ & $\begin{array}{l}14.4 \\
51.5\end{array}$ & $\begin{array}{l}34.2 \\
33.7\end{array}$ & $\begin{array}{l}73.0 \\
73.2\end{array}$ & $\begin{array}{l}8.1 \\
6.1\end{array}$ & $\begin{array}{r}18.1 \\
7.2\end{array}$ \\
\hline & \multicolumn{2}{|c|}{ GA meall } & 33.9 & 32.9 & 33.9 & 73.1 & 7.1 & 12.7 \\
\hline
\end{tabular}

1 Each figure represents the computed mean of 3 replicates.

for experiment 1. High $\mathrm{NO}_{3}$ failed to alleviate the desiccant action against leaf enzymes (table 9). Among plants given variable GA, Paraquat stimulated slightly the enzymes amylase and polyphenol oxidase (table 10). Phosphatase and ATP-ase were severely inhibited by Paraquat in the variety P.R. 980, whereas high GA eliminated the inhibition in P.R. 1059.

Especially striking was the desiccant suppression of leaf peroxidase (tables 9 and 10) which persisted regardless of variety, $\mathrm{NO}_{3}$, or GA treatment. Possible roles of peroxidase in cane have been dealt with at length 


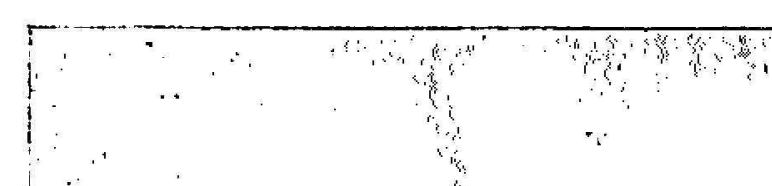

0 GRAM.

\section{$0.5 \%$ GRAM.}

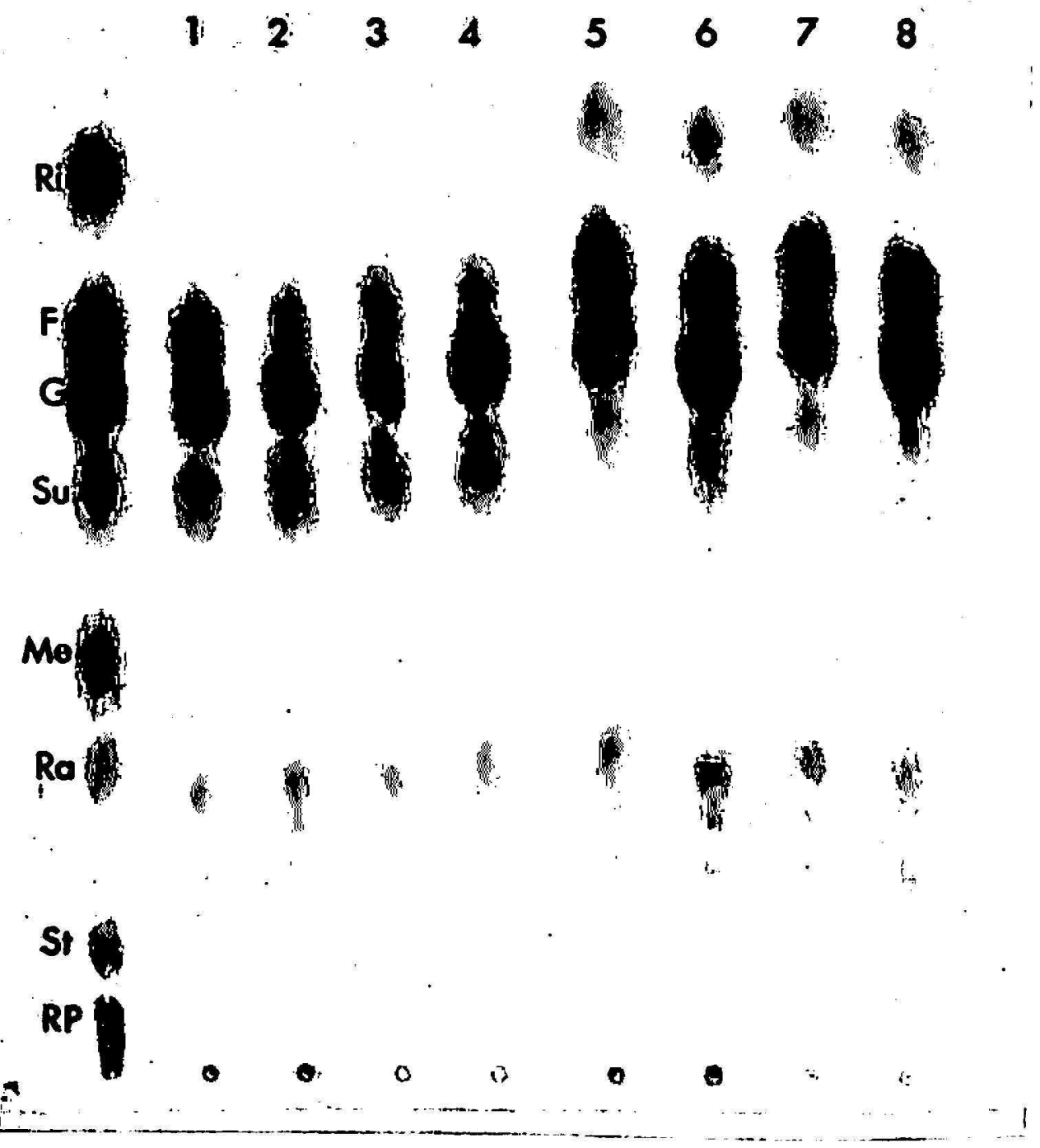

Fig. 5.-Paper chromatography of leaf extracts from cane treated with Paraquat (Gramoxone), and grown under variable conditions of variety, nitrate supply, and gibberellic acid treatment. Letters adjacent to reference sugars represent the following (from top to bottom): $\mathrm{Ri}$, ribose; $\mathrm{F}$, fructose; $\mathrm{G}$, glucose; $\mathrm{Su}$, sucrose; Me, melezitose; Ra, raffinose; St, stachyose; $R P$, ribose-5-phosphate. Numbers signify the following growth conditions established prior to desiccant application: $1=$ low GA, P.R. 980; $2=$ low GA, P.R. 1059; $3=$ high $\mathrm{NO}_{3}$, P.R. 980; $4=$ high $\mathrm{NO}_{3}$, P.R. 1059; $5=$ high GA, P.R. 980; $6=$ high GA, P.R. 1059; $7=$ high $\mathrm{NO}_{3}$, P.R. 980; $8=$ high $\mathrm{NO}_{3}$, P.R. 1059.

$(2,8)$. Although distinct correlations have been observed between peroxidase activity and sucrose level of cane tissues (2,3), the physiological basis of this relationship remains obscure.

Invertase was again markedly less active in plants treated with Paraquat 
TAвLE 9.-Mean specific activity values for leaf enzymses of cane treated with Paraquat and grown under conditions of nitrale stress ${ }^{1}$

\begin{tabular}{|c|c|c|c|c|c|c|c|c|}
\hline \multirow{2}{*}{ Var. } & \multirow{2}{*}{$\underset{\text { (meq./1.) }}{\mathrm{NO}_{3}}$} & \multirow{2}{*}{$\begin{array}{l}\text { Paraquat } \\
\text { (\% soln.) }\end{array}$} & \multicolumn{5}{|c|}{ Mean values for- } & \multirow[b]{2}{*}{ Mean } \\
\hline & & & $\begin{array}{l}\text { Phos- } \\
\text { phatase }\end{array}$ & $\underset{\text { ase }}{\text { ATP- }}$ & Amylase & $\begin{array}{l}\text { Poly- } \\
\text { phenol } \\
\text { oxidase }\end{array}$ & $\begin{array}{c}\text { Perox- } \\
\text { idase }\end{array}$ & \\
\hline \multirow[t]{2}{*}{ P.R. 980} & $\begin{array}{l}1.0 \\
50\end{array}$ & $\begin{array}{l}0 \\
0^{.5}\end{array}$ & $\begin{array}{l}51 \\
-^{2} \\
67 \\
49\end{array}$ & $\begin{array}{l}\frac{104}{-} \\
171 \\
105\end{array}$ & $\begin{array}{c}143 \\
- \\
170 \\
121\end{array}$ & $\begin{array}{c}3.7 \\
4.1 \\
2.0\end{array}$ & $\begin{array}{c}232 \\
\frac{-}{241} \\
144\end{array}$ & $\begin{array}{r}108 \\
131 \\
84\end{array}$ \\
\hline & \multicolumn{2}{|c|}{ Variety mean } & 56 & 127 & 145 & 3.3 & 207 & \\
\hline \multirow[t]{2}{*}{ P.R. 1059} & $\begin{array}{l}1.0 \\
50\end{array}$ & $\begin{array}{l}0 \\
0^{.5} \\
.5\end{array}$ & $\begin{array}{l}69 \\
\mathbf{2} \\
92 \\
52\end{array}$ & $\begin{array}{r}125 \\
168 \\
83\end{array}$ & $\begin{array}{r}188 \\
- \\
293 \\
94\end{array}$ & $\begin{array}{c}3.9 \\
- \\
2.8 \\
1.5\end{array}$ & $\begin{array}{c}185 \\
\frac{-}{273} \\
120\end{array}$ & $\begin{array}{r}114 \\
160 \\
70\end{array}$ \\
\hline & \multicolumn{2}{|c|}{ Variety mean } & 71 & 125 & 192 & 2.7 & 193 & \\
\hline
\end{tabular}

1 Each figure represents the computed mean of 3 replicates.

2 Data not available.

TARLE 10.-Mean specific activity values for leaf enzymes of cane trealed with Paraqual and grown under conditions of gibberellic acid stress ${ }^{1}$

\begin{tabular}{|c|c|c|c|c|c|c|c|c|}
\hline \multirow[b]{2}{*}{ Var. } & \multirow{2}{*}{$\begin{array}{c}\mathrm{GA} \\
(\% \text { soln. })\end{array}$} & \multirow{2}{*}{$\begin{array}{l}\text { Paraquat } \\
\text { (\% soln.) }\end{array}$} & \multicolumn{5}{|c|}{ Mean values for- } & \multirow[b]{2}{*}{ Mear } \\
\hline & & & $\begin{array}{l}\text { Phos- } \\
\text { phatase }\end{array}$ & ATP-ase & $\underset{\text { lase }}{\text { Amy- }}$ & $\begin{array}{l}\text { Poly- } \\
\text { phenol } \\
\text { oxidase }\end{array}$ & Peroxidase & \\
\hline \multirow[t]{2}{*}{ P.R. 980} & $\begin{array}{l}0 \\
.01\end{array}$ & $\begin{array}{l}0 \\
0.5 \\
0.5\end{array}$ & $\begin{array}{l}58 \\
32 \\
83 \\
46\end{array}$ & $\begin{array}{r}115 \\
58 \\
130 \\
70\end{array}$ & $\begin{array}{l}10 \\
24 \\
25 \\
32\end{array}$ & $\begin{array}{l}25 \\
29 \\
23 \\
28\end{array}$ & $\begin{array}{c}101 \\
5.5 \\
74 \\
4.3\end{array}$ & $\begin{array}{l}62 \\
30 \\
67 \\
36\end{array}$ \\
\hline & \multicolumn{2}{|c|}{ Variety mean } & 55 & 93 & 20 & 26 & 46 & \\
\hline P.R. 1059 & $\begin{array}{l}0 \\
.01\end{array}$ & $\begin{array}{l}0 \\
.5 \\
0 \\
.5\end{array}$ & $\begin{array}{l}82 \\
54 \\
54 \\
60\end{array}$ & $\begin{array}{r}117 \\
83 \\
98 \\
93\end{array}$ & $\begin{array}{l}32 \\
33 \\
12 \\
44\end{array}$ & $\begin{array}{l}24 \\
33 \\
17 \\
28\end{array}$ & $\begin{array}{c}99 \\
5.2 \\
71 \\
3.7\end{array}$ & $\begin{array}{l}71 \\
42 \\
50 \\
46\end{array}$ \\
\hline & \multicolumn{2}{|c|}{ Variety mean } & 63 & 98 & 30 & 26 & 44 & \\
\hline
\end{tabular}

1 Lach figure represents the computed mean of 3 replicates. 
(tables 11 and 12). High $\mathrm{NO}_{3}$ greatly increased relative invertase activity for P.R. 1059 but did not dispell the desiccant effect. Nor did GA counter the Paraquat inhibition except in the instance of P.R. 1059 where 0.01-percent GA suppressed invertase in control plants (table 12). Enzymes of immature storage tissue were generally more active in the plants treated with 0.01 percent GA.

\section{SIGNIFICANCE OF DESICCANT-SUGAR-ENZYME RELATIONSHIPS}

Several considerations have been raised which can contribute to future basic and applied research with cane desiccants. The principle of chemi-

TABLE 11.-Mean specific activily values for enzymes of immalure slorage tissue from cane treated with Paraqual and grown under conditions of nitrate stress ${ }^{1}$

\begin{tabular}{|c|c|c|c|c|c|c|c|c|c|}
\hline \multirow[b]{2}{*}{ Var. } & \multirow[b]{2}{*}{$\underset{(\mathrm{meq} . / 1 .)}{\mathrm{NO}_{2}}$} & \multirow[b]{2}{*}{$\begin{array}{l}\text { Paraquat } \\
(\% \text { soln.) }\end{array}$} & \multicolumn{6}{|c|}{ Mean values for- } & \multirow[b]{2}{*}{ Mean } \\
\hline & & & $\begin{array}{l}\text { Phos- } \\
\text { phatase }\end{array}$ & ATP-ase & $\begin{array}{c}\text { Amy- } \\
\text { lase }\end{array}$ & Invertase & $\begin{array}{l}\text { Poly- } \\
\text { phenol } \\
\text { oxidase }\end{array}$ & $\begin{array}{l}\text { Peroxi- } \\
\text { dase }\end{array}$ & \\
\hline \multirow[t]{2}{*}{ P.R. 980} & $\begin{array}{l}1.0 \\
50\end{array}$ & $\begin{array}{l}0 \\
.5 \\
0.5\end{array}$ & $\begin{array}{r}83 \\
-2 \\
92 \\
128\end{array}$ & $\begin{array}{l}\frac{102}{-} \\
125 \\
160\end{array}$ & $\begin{array}{l}\frac{16}{17} \\
24\end{array}$ & $\begin{array}{l}12 \\
- \\
13 \\
3.1\end{array}$ & $\begin{array}{l}34 \\
24 \\
29\end{array}$ & $\begin{array}{c}76 \\
- \\
62 \\
110\end{array}$ & $\begin{array}{l}54 \\
56 \\
80\end{array}$ \\
\hline & \multicolumn{2}{|c|}{ Variety mean } & 101 & 129 & 19 & 9.3 & 29 & 83 & \\
\hline P.R. 1059 & $\begin{array}{r}1.0 \\
50\end{array}$ & $\begin{array}{l}0 \\
. .5 \\
0.5\end{array}$ & $\begin{array}{l}113 \\
-2 \\
170 \\
177\end{array}$ & $\begin{array}{l}161 \\
- \\
230 \\
230\end{array}$ & $\begin{array}{l}27 \\
35 \\
53\end{array}$ & $\begin{array}{c}13 \\
- \\
21 \\
12\end{array}$ & $\begin{array}{l}51 \\
38 \\
65\end{array}$ & $\begin{array}{l}50 \\
\overline{50} \\
31\end{array}$ & $\begin{array}{l}69 \\
91 \\
96\end{array}$ \\
\hline & \multicolumn{2}{|c|}{ Variety mean } & 153 & 209 & 38 & 15 & 51 & 44 & \\
\hline
\end{tabular}

1 Each figure represents the computed mean of 3 replicates.

2 Data not available.

cally drying cane foliage to insure uniform burning may be incompatible with the principle of cane ripening until the following problems are solved:

1. Foliar desiccation appears to defeat its own purpose if photosynthesis is curtailed too early. The preharvest ripened condition usually represents a carefully contrived balance in which sugar storage exceeds utilization. By inhibiting photosynthesis while metabolic enzymes remain active, the plant may continue to lose sucrose at a time when photosynthate input has dropped to zero. Putting this another way, the grower may force cane to invert its reserves at a time when it can no longer repair the losses. During the first Paraquat experiment pentose appeared in leaves by 48 hours, in- 
dicating an impaired photosynthetic mechanism, while amylase remained excessively active until after 72 hours. Thus, in spite of successful invertase suppression, Brix and polarization values deteriorated.

2. A biochemically acceptable desiccant should be specific and selective in its mode of action against enzymes. The invertase suppression noted for Paraquat could have been highly desirable had the chemical not altered the

TABLE 12.-Mean specific activity values for enzymes of immature storage tissue from cane treated with Paraqual and grown under conditions of gibberellic acid siress ${ }^{1}$

\begin{tabular}{|c|c|c|c|c|c|c|c|c|c|}
\hline \multirow{2}{*}{ Var. } & \multirow{2}{*}{$\begin{array}{c}\text { GA } \\
\text { (\% soln.) }\end{array}$} & \multirow{2}{*}{$\begin{array}{l}\text { Paraquat } \\
\text { (\% soln.) }\end{array}$} & \multicolumn{6}{|c|}{ Mean values for- } & \multirow[b]{2}{*}{ Mean } \\
\hline & & & $\begin{array}{l}\text { Phos- } \\
\text { phatase }\end{array}$ & ATP-ase & Amylase & Invertase & $\begin{array}{l}\text { Poly- } \\
\text { phenol } \\
\text { oxidase }\end{array}$ & $\begin{array}{c}\text { Peroxi- } \\
\text { dase }\end{array}$ & \\
\hline \multirow[t]{3}{*}{ P.R. 980} & 0 & $\begin{array}{l}0 \\
.5\end{array}$ & $\begin{array}{l}48 \\
44\end{array}$ & $\begin{array}{r}100 \\
71\end{array}$ & $\begin{array}{l}14 \\
14\end{array}$ & $\begin{array}{l}13 \\
3.1\end{array}$ & $\begin{array}{l}16 \\
11\end{array}$ & $\begin{array}{l}58 \\
43\end{array}$ & $\begin{array}{l}42 \\
31\end{array}$ \\
\hline & \multicolumn{2}{|c|}{ GA mean } & 46 & 85 & 14 & 8.0 & 13.5 & 51 & 37 \\
\hline & .01 & $\begin{array}{l}0 \\
.5\end{array}$ & $\begin{array}{l}82 \\
53\end{array}$ & $\begin{array}{l}99 \\
81\end{array}$ & $\begin{array}{l}14 \\
20\end{array}$ & $\begin{array}{r}15 \\
4\end{array}$ & $\begin{array}{c}16 \\
8.6\end{array}$ & $\begin{array}{l}47 \\
61\end{array}$ & $\begin{array}{l}46 \\
38\end{array}$ \\
\hline & \multicolumn{2}{|c|}{ GA mean } & 68 & 90 & 17 & 9.5 & 12.3 & 54 & 42 \\
\hline \multirow[t]{4}{*}{ P.R. 1050} & 0 & $\begin{array}{l}0 \\
.5\end{array}$ & $\begin{array}{r}108 \\
44\end{array}$ & $\begin{array}{r}179 \\
59\end{array}$ & $\begin{array}{l}30 \\
4.8\end{array}$ & $\begin{array}{r}19 \\
9\end{array}$ & $\begin{array}{l}26 \\
11\end{array}$ & $\begin{array}{l}70 \\
27\end{array}$ & $\begin{array}{l}72 \\
26\end{array}$ \\
\hline & \multicolumn{2}{|c|}{ GA mean } & 76 & 119 & 17.4 & 14 & 19 & 49 & 49 \\
\hline & .01 & $\begin{array}{l}{ }^{0} .5 \\
\end{array}$ & $\begin{array}{l}129 \\
119\end{array}$ & $\begin{array}{l}145 \\
142\end{array}$ & $\begin{array}{l}61 \\
42\end{array}$ & $\begin{array}{l}5.6 \\
5.0\end{array}$ & $\begin{array}{l}21 \\
15\end{array}$ & $\begin{array}{l}71 \\
87\end{array}$ & $\begin{array}{l}72 \\
68\end{array}$ \\
\hline & \multicolumn{2}{|c|}{ GA mean } & 124 & 144 & 52 & 5.3 & 18 & 79 & 70 \\
\hline
\end{tabular}

1 Each figure represents the computed mean of 3 replicates.

behavior of other catalysts. The early small sucrose and Brix increases probably reflect invertase suppression. Yet Paraquat apparently blocked an essential photosynthetic enzyme (phosphoribose isomerase) while leaving active a phosphatase (ribose-5-phosphatase), and a greatly stimulated amylase. Much evidence has been gathered here pointing up a need for suppression of both invertase and amylase for high sucrose $(19,15,17)$. Programs for evaluating desiccants could do worse than to include foliar analyses of these two enzymes.

3. The objective of desiccating cane foliage until physically dry may be 
more severe than necessary. Withholding water from cane is an established method for ripening where water supply can be controlled $(26,32,33)$. This in itself discourages the new succulent growth which resists uniform burning. Hartt $(30,31)$ has shown that water withdrawal poses greater difficulty for sugar transport than for photosynthesis, and when both processes are impaired by restricted moisture there may still be an apparent increase of sucrose. With this in mind a more practical objective should be a wilted but green top, one no longer making growth but still active photosynthetically. Such a condition might be achieved with lesser desiccant concentrations. Another approach is the use of chemicals which can destroy specific growing points without interfering with photosynthesis. In the latter context the pyrimidine analog 6-azauracil has shown promise in Puerto Rico $(18,15,17)$.

\section{SUMMARY}

Two experiments are reported in which sugar and enzyme transformations were measured in immature sugarcane treated with Paraquat $\left(1,1^{\prime}\right.$-dimethyl-4, $4^{\prime}$-bipyridilium salt). The chemical is a powerful desiccant whose effects on sugar yield have been inconsistent. There were two objectives: 1 , To determine whether sugar changes could be correlated with abnormal behavior of hydrolytic or oxidative enzymes; and 2, to verify the persistence of sugar and enzyme changes in two varieties under conditions of high nitrate $\left(\mathrm{NO}_{3}\right)$ and gibberellic acid (GA) growth stimulation. All plants were grown by sand culture in the greenhouse.

For experiment 1, growth, sugar, and enzyme data were taken periodically following a single foliar treatment of 0.5-percent Paraquat on 16-week old plants of the variety P.R. 980. The second experiment employed variable $\mathrm{NO}_{3}$ (1.0 and 50 meq./liter) and GA (0 and 0.01 percent solutions) to establish extreme growth regimes prior to Paraquat treatment. Plants were harvested once 7 days after desiccant application.

The following results were obtained:

1. All Paraquat-treated plants were visibly wilted within 8 hours after treatment. Leaf and spindle tissues were severely wilted within 36 hours and foliar discoloration had begun. At 72 hours the spindle, leaf, and sheath tissues were desiccated and a greyish-yellow color was predominant.

2. Severe loss of leaf sucrose was detected within 24 hours. Brix and polarization values were low at $\mathbf{7 2}$ hours and had declined still further at 168 hours.

3. An excessive rise in leaf amylase activity accompanied the leaf sucrose decline. This supports an earlier theory that active amylase stimulates a drain of glucose-1-phosphate reserves into polysaccharide synthesis.

4. Paper chromatography revealed the appearance of ribose in desiccated leaves between 24 and 48 hours after treatment. This is believed to signify a 
blockage of photosynthesis during the conversion of triose phosphate to pentose phosphate. It is suggested that action of a phosphoribose isomerase is blocked, and subsequent accumulations of ribose-5-phosphate are hydrolyzed by ribose-5-phosphatase. Raffinose, a trisaccharide bearing a sucrose linkage, and several sugars of lesser mobility increased in Paraquattreated leaves. Increased activity of a transferase employing sucrose as a hexose acceptor is suspected.

5. Invertase in immature storage tissue was suppressed by Paraquat. This possibly accounts for initial increases of Brix values and of sucrose in immature storage tissues.

6. Immature storage tissue enzymes were generally less affected by Paraquat than leaf enzymes. All leaf enzymes, peroxidase in particular, eventually declined in response to Paraquat.

7. Growth, sugar, and enzyme changes induced by Paraquat generally persisted regardless of variety, $\mathrm{NO}_{3}$, or $\mathrm{GA}$ variables.

8. GA-treated plants of both varieties were more severely desiccated than controls. GA increased internode length and weight of stalks, but did not permit greater stalk desiccation.

9. Three conclusions were drawn as guidelines for future desiccant research:

a. Foliar desiccation appears to defeat its own purpose if photosynthesis is curtailed too early.

b. A biochemically acceptable desiccant must be specific and selective in its action against enzymes.

c. The objective of cane desiccation should be a wilted top, no longer growing, but one still green and photosynthetically active.

\section{RESUMEN}

Se informan los resultados de dos experimentos en los que se evaluaron las transformaciones de las enzimas y el azúcar en caña de azúcar inmadura tratada con Paraquat (sal de $1,1^{\prime}$-dimetilo-4, $4^{\prime}$-bipiridilio). El Paraquat es un desecante potente cuyos efectos en el rendimiento de azúcar han sido inconsistentes. Eran dos los objectivos: 1, Determinar si los cambios quimicos podían correlacionarse con un comportamiento anormal de enzimas hidroliticas u oxidantes; y 2, verificar la persistencia de los cambios en el azúcar y las enzimas en dos variedades de caña tratadas con cantidades elevadas de nitrato $\left(\mathrm{NO}_{8}\right)$ y ácido giberélico (AG) para estimular el crecimiento. Todas las plantas se sembraron en arena en un invernadero.

En el primer experimento se tomaron periódicamente datos del crecimiento, el azúcar y las enzimas después de aplicar una sola aspersión foliar con Paraquat al 0.5 por ciento a plantas de la variedad P.R. 980 de 16 semanas de sembradas. En el segundo experimento se usaron diversas concentra- 
ciones de $\mathrm{NO}_{3}$ (1.0 y 50 meq./litro) y AG (soluciones al 0 y 0.01 por ciento) para establecer regímenes extremos de crecimiento antes del tratamiento con Paraquat. Se cosechó una sola vez a los 7 días, después de la aplicación del desecante.

Los resultados fueron los siguientes:

1. Todas las plantas tratadas con Paraquat se marchitaron visiblemente dentro de las primeras 8 horas de haberse aplicado el tratamiento. Los tejidos de la hoja y el cogollo se marchitaron severamente durante un lapso de 36 horas, habiendo comenzado ya a descolorarse las hojas. A las 72 horas los tejidos del cogollo, las hojas y las yaguas estaban secos y predominaba un color amarillo-grisáceo.

2. Se notó una pérdida considerable de la sacarosa foliar dentro de las 24 horas. Los valores del Brix y la polarización fueron bajos a las 72 horas y habían disminuido más aún a las 168 horas.

3. Un excesivo aumento en la actividad de la amilasa foliar acompañó un descenso de la sacarosa foliar. Esto sostiene la teoría anterior de que la amilasa activa estimula un agotamiento de las reservas de glucosa-1-fosfato en la sintesis de los polisacáridos.

4. La cromatografía sobre papel reveló la aparición de ribosa en las hojas desecadas entre las 24 y 48 horas posteriores al tratamiento. Se cree que ésto significa que hubo un bloqueo en la fotosíntesis durante la conversión del fosfato de triosa al fosfato de pentosa. Se sugiere que la acción de la isomerasa de fosforribosa es bloqueada, y las acumulaciones subsiguientes de ribosa-5-fosfato son hidrolizadas por la ribosa-5-fosfatasa. La rafinosa, un trisacárido que tiene un enlace de sacarosa, y otros azúcares de menor movilidad aumentaron en las hojas tratadas con Paraquat. Se sospecha que haya tenido lugar un aumento en la actividad de una transferasa que emplea la sacarosa como receptora de la hexosa.

5. La invertasa del tejido reservante tierno fue suprimida por el Paraquat. Esto posiblemente explique los aumentos iniciales en los valores del Brix y de la sacarosa en el tejido reservante tierno.

6. Las enzimas del tejido reservante tierno fueron afectadas en menor grado por el Paraquat que las enzimas foliares. Todas las enzimas foliares, la peroxidasa en particular, disminuyeron eventualmente debido al efecto del Paraquat.

7. Los cambios en el crecimiento, el azúcar y las enzimas inducidos por el Paraquat persistieron generalmente sin importar la variedad y las cantidades variables de $\mathrm{NO}_{3}$ o $\mathrm{AG}$.

8. Las plantas de ambas variedades tratadas con $A G$ se desecaron mucho más que las testigo. El AG alargó los entrenudos y aumentó el peso de los tallos, pero no permitió un desecamiento mayor de los últimos.

9. Se dedujeron tres conclusiones que pueden servir de directrices para la investigación futura de los desecantes: 
a. La desecación foliar parece anular su propio propósito, si la fotosíntesis se restringe muy temprano.

b. Un desecante bioquímicamente aceptable debe ser específico $y$ selectivo en su acción contra las enzimas.

c. El objetivo de la desecación en la caña de azúcar debería ser un cogollo marchito y de crecimiento interrumpido, pero aún verde $y$ fotosintéticamente activo.

\section{LITERATURE CITED}

1. Alers, S., and Samuels, G., The topping of sugarcane, J. Agr. Univ. P.R. 47 (4): 257-64, 1963.

2. Alexander, A. G., Sucrose-enzyme relationships in immature sugarcane as uffected by varying levels of nitrate and potassium supplied in sand culture, $J . A g r$. Univ. P.R. 48 (3): 165-231, 1964.

3. Changes in leaf-sugar content and enzyme activity of immature sugarcane following foliar application of indole-3-acetic acid, 2,4-dichlorophenoxyacetic acid, and maleic hydrazide, J. Agr. Univ. P.R. 49 (1): 1-34, 1365.

4. - - Physiological st udies of enzymes catalyzing the synthesis and hydrolysis of sucrose, starch, and phosphorylated hexose in sugarcane, J. Agr. Univ. P.R. 49 (1): 60-75, 1965.

5. - Hydrolytic proteins of sugarcane. The acid phosphatases, J. Agr. Univ. P.R. 49 (2): 204-28, 1965.

6. - Hydrolytic proteins of sugarcane. The acid invertases, J. Agr. Univ. P.R. 49 (3): 287-307, 1965.

7. - Hydrolytic proteins of sugarcane. Amylase, J. Agr. Univ. P.R. 49 (3): 308-24, 1965.

8. - Oxidizing enzymes of sugarcane. Peroxidase, J. Agr. Univ. P.R. 50 (1): $36-52,1966$.

9. - Oxidizing enzymes of sugarcane. Tyrosinase, J. Agr. Univ. P.R. 50 (2): 113-30, 1966.

10. - High sucrose content and abnormal enzyme activity as a function of nutritional stress in sugarcane, $J$. Agr. Univ. P.R. 51 (4): 325-33, 1967.

11. - Interrelationships of gibberellic acid and nitrate in sugar production and enzyme activity of sugarcane, J. Agr. Univ. P.R. 52 (1): 19-28, 1968.

12. - - Action patterns of sugarcane acid invertase, J. Agr. Univ. P.R. 51 (2): 154-66, 1967.

13. - Growth, enzyme, and sugar responses of immature sugarcane to foliar treatment with 6-azauracil and gibberellic acid, J. Agr. Univ. P.R. 52 (4): 295-310, 1968.

14. - In vitro effects of silicon on the action patterns of stgarcane acid invertase, J. Agr. Univ. P.R. 52 (4): 311-22, 1968.

15. - The potential of sugarcane to produce sucrose, Proc. Int. Soc. Sugar Cane T'echnol., XIII Cong., Taiwan, 1368.

16. - Effects of combined silicon and gibberellic acid on sugar and enzyme constituents of immature sugarcane grown in sand culture, Proc. Int. Soc. Sugar Cane Technol., XIII Cong., Taiwan, 1968.

17. - - Interrelationships of nitrate and 6-azauracil in the growth, enzymology, and sucrose production of immature sugarcaie, J. Agr. Univ. P.R. Es (2): 81-92, 1969.

18. Alexander, A. G., and Samuels, G., Controlled-temperature studies of growth, 
enzymology and sucrose production by two sugarcane varieties in Puerto Rico, J. Agr. Univ. P.R. 52 (3): 204-17, 1968.

19. Axelrod, B., and Jang, R., Purification of phosphoriboisomerase from alfalfa, J. Biol. Chem. 209: 847-55, 1954.

20. Bassham, J. A., Photosynthesis: The path of carbon, Chapter 34 in: Bonner, J. and Varner, J. E., Plant Biochemistry, Academic Press, New York, N.Y., 1965.

21. Bates, J. F., Preliminary trials with desiccants in sugarcane, Proc. British II. Ind. Sug. Technol. 43-48, 1960.

22. Benson, A. A., Bassham, J. A., Calvin, M., Goodale, T. C., Hass, V. A., and Stepka, W., The path of carbon in photosynthesis. V. Paper chromatography and radioautography of the products, $J$. Am. Chem. Soc. 72: 1710-18, 1952.

23. Calvin, M., and Benson, A. A., The path of carbon in photosynthesis, Science 107: 476-80, 1948.

24. - The path of carbon in photosynthesis: IV. The identity and sequence of the intermediates in sucrose synthesis, Science 109: 140-42, 1949.

25. Cardini, C. E., Leloir, L. F., and Chiriboga, J., The biosynthesis of sucrose, $J$. Biol. Chem. 214: 149-55, 1955.

26. Clements, H. F., Shigeura, G., and Akamine, E. F., Factors affecting the growth of sugarcane, Univ. Haw., Agr. Exp. Sta. Tech. Bull. No. 18, 1952.

27. Davidson, L. (i., Lffects of desiccants on sugarcane, Proc. Int. Soc. Sugar Cane Technol., XI Cong., 319-23, 1962.

28. Dube, S. K., and Nordin, P., Isolation and properties of sorghum alpha-amylase, Arch. Biochem, and Biophy/s. 94: 121-7, 1961.

29. Gosnell, J. M., and Thompson, (i. D)., The effects of Paraquat on the growth and yield of sugarcane, Proc. Int. Soc. Sugar Cane Technol., XII Cong., 493-500, 1965.

30. Hartt, C. L., Translocation of sugar in the cane plant, Ann. Rept. Haw. Sugar Tech. 1963-64: 151-67.

31. - Effect of moisture supply upon translocation and storage of ${ }^{4} \mathrm{C}$ in sugarcane, Plant Physiol. 42 (3): 338-46, 1967.

32. Humbert, R. P., Zamora, M., and Fraser, T. B., Ripening and maturity control progress at Ingenio Los Mochis, Mexico, Pre Print No. 108, Proc. Int. Soc. Sugar Cane Technol., XII Cong., 1965.

33. Ranganathan, V., A note on the hydration of cane sheaths as an indicator of maturity, Ind. J. Sugar C'ane Res. Dev. 4 (1): 50-51, 1959.

34. Robson, J. W., and Procter, (i. C., Paraquat as a herbicide and desiccant in tropical agriculture, World Crops 15 (6): $264,1963$.

35. Roe, J. R., A colorimetric method for the determination of fruetose in bloud and urine, J. Biol. Chem. 107: 15-22, 1934.

36. Sumner, J. B., 1)initrusalicylic acid: A reagent for estimation of sugar in normal and diabetic urine, J. Biol. Chem. 47: 5-9, 1921.

37. Sutherland, E. W., Cori, C. F., IIaynes, R., and Olsen, N. S., Purification of the hyperglycemic-glycogenolytic factor from insulin and gastric mucosa, $J$. Biol. Chem. 180: 825-37, 1949. 